\title{
STIMULASI GERAK LOKOMOTOR ANAK USIA 1-4 TAHUN MELALUI METODE GERAK DAN LAGU
}

\author{
Intan Nisa ${ }^{1}$; Suwardi ${ }^{1}$ \\ ${ }^{1}$ Program Studi Pendidikan Guru Pendidikan Anak Usia Dini, Fakultas Psikologi dan Pendidikan, \\ Universitas Al-Azhar Indonesia, Jalan Sisingamangaraja, Kebayoran Baru, Jakarta Selatan 12110 \\ Penulis untuk Korespondensi/ E-mail: suwardi@uai.ac.id
}

\begin{abstract}
Abstrak - Gerak lokomotor sangat melekat erat dan tidak dapat dipisahkan pada perkembangan motorik kasar anak, untuk itu perlu dilakukan stimulasi terkait kemampuan gerak lokomotornya yang sesuai dengan kelompok usia. Metode penelitian yang digunakan metode kualitatif dengan pendekatan deskriptif. Teknik pengumpulan data yang digunakan adalah wawancara, observasi dan dokumentasi. Sumber data penelitiannya itu koordinator, guru play class, serta orangtua play class. Hasil penelitian menunjukkan bahwa pada kelompok kelas Runner (16-24 bulan) stimulasi kemampuan berjalan, berlari dan melompat dilakukan dengan menggunakan lagu walk jump run, chochoc train, welcome to little jack, serta good bye song. Pada kelompok kelas Explorer (2-3 tahun) stimulasi kemampuan berjalan, berlari dan melompat dilakukan denganmenggunakan lagu walk jump run, chochoc train, welcome to little jack, jumping jack, serta good bye song. Sementara pada kelompok Kiddos (3-4 tahun) pada kelompok kelas Explorer (2-3 tahun) menstimulasi kemampuan berjalan, berlari dan melompat menggunakan lagu walk jump run, chochoc train, welcome to little jack, jumping jack, serta good bye song. Pemberian stimulasi gerak lokomotor pada masing-masing usia, beberapa sudah sesuai dengan prinsip dasar stimulasi namun belum disesuaikan dengan usia atau kelompok anak seperti yang terdapat pada kriteria pemilihan media yakni pengelompokan sasaran. Saran yang dapat diberikan terkait stimulasi gerak dan lagu yang diberikan, hendaknya media yang digunakan diklasifikasikan berdasarkan kelompok usia. Sebaiknya pihak sekolah memberikan kegiatan dengan memperhatikan Peraturan Menteri 146 tahun 2014 serta guru dapat menggunakan media pembelajaran yang sesuai dengan usia anak, agar kemampuan anak dapat berkembang sesuai tahapan dan usianya.
\end{abstract}

Kata Kunci: Stimulasi, Gerak lokomotor, Gerak dan Lagu

Abstract - The locomotor motion is very closely attached and cannot be separated from the gross motoric development of the child, so stimulation is needed regarding the locomotor motion ability that is in accordance with the age group. The research method used is qualitative methods with a descriptive approach. Data collection techniques used were interviews, observation and documentation. Research data sources are coordinator, play class teacher, and parent play class. The results showed that in the Runner class (16-24 months) the stimulation of the ability to walk, run and jump was carried out using the walk jump run song, chochoc train, welcome to little jack, and good bye song. In the class Explorer group (2-3 years) the stimulation of the ability to walk, run and jump was carried out using the walk jump run, chochoc train, welcome to little jack, jumping jack, and good bye song. While in the Kiddos group (3-4 years) in the Explorer class (2-3 years) stimulated the ability to walk, run and jump using the walk jump runsong, chochoc train, welcome to little jack, jumping jack, and good bye song. Giving locomotor motion stimulation at each age of several has been in accordance with some basic principles of stimulation but has not been adjusted to the age or group of children as found in the selection criteria of the media namely target grouping. Suggestions that can be given are related to motion stimulation and songs given, should the media used be classified according to age group. It is better for the school to provide activities by taking into account the Minister of Agriculture Regulation 146 of 2014 and for teachers to use learning media that are appropriate to the age of the child, so that the child's ability to develop according to the stages and age.

Keyword: Stimulation, Locomotor motion, Music And Movement 


\section{PENDAHULUAN}

$\mathrm{P}$ endidikan Anak usia dini (PAUD) merupakan upaya pembinaan dan pengasuhan yang ditujukan kepada anak sejak lahir hingga usia 6 tahun, Pendidikan bagi anak usia dini dilakukan melalui pemberian rangsangan pendidikan untuk membantu pertumbuhan dan perkembanganjasmani dan rohani agar anak memiliki kesiapan dalam memasuki pendidikan lebih lanjut (UndangUndang Nomor 20 Tahun 2003). Tujuannya adalah membantu mengembangkan seluruh potensi dan kemampuan fisik, intelektual, emosional, moral dan agama secara optimal dalam lingkungan pendidikan yang kondusif.

Seluruh aspek perkembangan anak saling berkaitan dan mempengaruhi pertumbuhan dan perkembangan anak selanjutnya. Salah satu aspek perkembangan yang memiliki potensi yang sangat besar pada anak usia dini yakni perkembangan fisik motorik. Menurut Alawiyah (2014: 2) dalam penelitiannya yang berjudul Peningkatan Keterampilan Motorik Kasar Melalui Permainan Tradisional Banten mengatakan bahwa motorik kasar merupakan kemampuan seseorang dalam menggunakan otot-otot besar dengan menggunakan seluruh tubuh atau sebagian tubuh mereka dengan benar, dengan memperhatikan tahapan belajar motorik, sehingga seseorang dapat melakukan gerakan yang diinginkannya, seperti gerakan koordinasi mata dan kaki serta gerakan kordinasi mata dan tangan. Agar anak dapat melakukan gerakan motorik dengan optimal maka diperlukan adanya stimulasi baik dari orangtua maupun guru.

\section{Pengertian Stimulasi}

Di dalam buku yang dikeluarkan oleh Departemen Pendidikan Nasional Direktort Pembinaan Taman Kanak-Kanak dan Sekolah Dasar (2008: 7) tertulis bahwa stimulus adalah intruksi verbal dari guru atau bentuk gerakan yang ditampilkan yang diterima anak harus sederhana dan jelas, sehingga tidak menyebabkan kesalahan gerakan yang dilakukan. Pada tahap awal pemahaman anak terhadap intruksi yang diterima masih harus membutuhkan waktu yang cukup lama untuk mampu melaksanakan tugas dengan benar.
Sementara itu menurut Kementerian Kesehatan Republik Indonesia (2012: 11), di dalam Pedoman Deteksi Dini Tumbuh Kembang Balita, stimulasi adalah kegiatan merangsang kemampuan dasar anak agar anak tumbuh dan berkembang secara optimal. Setiap anak perlu mendapat stimulasi rutin sedini mungkin dan terus menerus pada setiap kesempatan. Stimulasi tumbuh kembang anak dilakukan oleh ibu dan ayah yang merupakan orang terdekat dengan anak, anggota keluarga lain dan kelompok masyarakat di lingkungan rumah tangga masing - masing dan dalam kehidupan sehari - hari seperti guru.

Lebih lanjut di dalam buku Pedoman Deteksi Dini Tumbuh Kembang Balita juga tertuliskan bahwa terdapat prinsip dasar dalam memberikan stimulasi, yaitu: Stimulasi dilakukan dengan landasan rasa cinta dan kasih sayang; selalu tunjukkan sikap dan perilaku yang baik, karena anak akan meniru tingkah laku orang - orang terdekat dengannya; berikan stimulasi sesuai dengan kelompok umur anak; lakukan stimulasi dengan cara mengajak anak bermain, bernyanyi, menyenangkan, tanpa paksaan dan tidak ada hukuman; lakukan stimulasi secara bertahap dan berkelanjutan sesuai umur anak terhadap ke-4 aspek kemampuan dasar anak; gunakan alat bantu/ permainan yang sederhana, aman dan ada di sekitar anak; beri kesempatan yang sama pada anak laki - laki dan perempuan; dan anak selalu diberi pujian, bila perlu diberi hadiah atas keberhasilannya.

Prinsip-prinsip stimulasi tersebut tentu harus dapat dipahami oleh pendidik, baik rangtua maupun guru. Hal ini bertujuan agar stimulasi yang diberikan sesuai dengan apa yang seharusnya dilakukan dan dapat mencapai hasil yang diharapkan.

\section{Pengertian Motorik Kasar}

Papalia (2009: 194) menuliskan bahwa keterampilan motorik kasar adalah keterampilan fisik yang melibatkan otot besar. Sementara itu menurut Santrock (2007: 210), motorik kasar merupakan keterampilan yang meliputi aktivitas otot besar, seperti menggerakan lengan dan berjalan. Pada dasarnya gerakan motorik dapat diklasifikasikan ke dalam gerakan lokomotor, gerakan non-lokomotor, dan gerakan manipulative (Samsudin, 2008: 9) 
Gerak lokomotor merupakan gerak yang umum dilakukan manusia dalam kesehariannya. Menurut Lutan (2010: 41), gerak lokomotor adalah setiap gerak yang dilakukan dalam keadaan tubuh dipindahkan posisinya ke arah mendatar (horizontal) atau ke arah vertical dari titik satu ke titik lainnya dalam sebuah ruang. Adapun yang termasuk dalam gerakan lokomotor adalah berjalan, berlari, melompat, meloncat, merayap, menghindar, berhenti. Keterampilan gerak lokomotor ini digunakan untuk memindahkan tubuh dari satu tempat ke tempat lain atau untuk mengangkat tubuh ke atas seperti lompat dan loncat. Kemampuan gerak lainnya adalah berjalan, berlari, skipping, berguling, melompat, meluncur dan larisepertikudaberlari (gallop) (Saputra (2005: 18).

Keterampilan motorik kasar kedua adalah keterampilan Non-Lokomotor. Keterampilan ini dilakukan di tempat, tanpa ada ruang gerak yang memadai. Kemampuan non-lokomotor terdiri dari menekuk dan meregang, mendorong dan menarik, mengangkat dan menurunkan, melipat, mengocok, melingkar, melambungkan, membengkokan dan meluruskan, keseimbangan, bergoyang, memutar, meluncur dan lain-lain (Samsudin, 2007:9)

Keterampilan motorik kasar yang ketiga adalah keterampilan manipulative dikembangkan ketika anak tengah menguasai macam-macam objek. Kemampuan manipulative lebih banyak melibatkan tangan dan kaki, tetapi bagian lain dari tubuh juga dapat digunakan. Bentuk-bentuk dari kemampuan manipulative adalah melempar, memukul, menendang, gerakan menerima menangkap, berguling, melambungkan dan lain-lain.

\section{Gerak Dasar Lokomotor}

Gerak dasar lokomotor terbagi menjadi beberapa keterampilan di antaranya:

\section{Berjalan}

Menurut Graham dkk (dalam Faruq 2007: 7), berjalan adalah proses pergantian hilangnya keseimbangan dan mengembalikan keseimbangan dengan menggerakan kaki maju ke depan dalam posisi yang benar secara bergantian. Sedangkan menurut Samsudin (2007: 76) dalam buku Permainan Kecerdasan
Kinestetik, berjalan merupakan dasar gerak perpindahan tempat atau lokomotor, selain itu berjalan merupakan keterampilan dasar yang paling sering digunakan sehari-hari.

\section{Berlari}

Gerakan berlari merupakan perkembangan dari gerakan berjalan. Gerakan dasar anggota tubuh pada saat berlari menyerupai gerakan berjalan. Perbedaannya terletak pada iramanya yang lebih cepat. Menurut Djumidar (2004: 13) dalam buku belajar berlatih gerak-gerak dasar atletik dalam bermain mengatakan bahwa, lari adalah frekuensi langkah yang dipercepat sehingga pada waktu berlari ada kecenderungan badan melayang.

Perkembangan gerak berlari anak usia dini dicapai secara bertahap untuk bisa menjadi lebih baik. Karakteristik gerakan berlari mulamula bisa dilakukan oleh anak adalah gerakan langkah masih terbatas rentangnya dan ayunan lengan tangan tidak sepenuhya ke depan dan ke belakang melainkan cenderung ke arah samping (Sumantri, 2005: 75).

\section{Melompat}

Menurut Djumidar (2004), lompat adalah salah satu gerakan mengangkat tubuh dari satu titik ke titik yang lain dengan ancang-ancang lari cepat atau lambat dengan menumpu pada kaki serta anggota tubuh lainnya dengan keseimbangan yang baik. Untuk menstimulasi gerak dasar ini, dapat dilakukan dalam beberapa aktivitas. Beaty (2013: 205) mengatakan bahwa ada beberapa aktivitas yang dapat membantu anak agar dapat melompat yakni dengan bermain melompat dengan konsep, bermain menirukan lompatan hewan dan membacakan sebuah buku. Ketiga klasifikasi tersebut merupakan gerakan yang mendasari aktivitas fisik yang lebih kompleks seperti yang banyak terlihat dalam kegiatan berolah raga maupun dalam bermain.

\section{Perkembangan Gerak Lokomotor Anak Usia 1-4 Tahun}

Perkembangan Gerak lokomotor pada anak usia dini berbeda-beda. Di dalam Peraturan Menteri Pendidikan dan Kebudayaan Republik Indonesia nomor 146 tahun 2014, anak usia 1-2 tahun sudah mampu mengenal anggota tubuh, 
fungsi dan gerakannya untuk pengembangan motorik kasar dan halus. Seperti anak sudah mampu berjalan sendiri tanpa jatuh, melompat di tempat, naik turun tangga atau tempat yang lebih tinggi dengan bantuan, berjalan mundur beberapa langkah.

Kemudian pada usia 2-3 tahun anak sudah mampu berjalan sambil berjinjit, melompat ke depan dan ke belakang dengan dua kaki, menari mengikuti irama, naik turun tangga atau tempat yang lebih tinggi/ rendah dengan berpegangan. Sementara anak usia 3-4 tahun sudah mampu berlari sambil membawa sesuatu yang ringan (bola), naik turun tangga atau tempat yang lebih tinggi dengan kaki bergantian, meniti di atas papan yang cukup lebar, melompat turun dari ketinggian kurang lebih $20 \mathrm{~cm}$ (di bawah tinggi lutut anak), meniru gerakan senam sederhana seperti menirukan gerakan pohon, dan kelinci melompat.

\section{Pengertian Gerak dan Lagu}

Menurut Gallahue yang dikutip oleh Mutiah (2010: 168) dalam buku Psikologi Bermain Anak Usia dini dinyatakan bahwa gerak dan lagu adalah kegiatan bernyanyi sambil bergerak sesuai dengan irama musik. Sementara itu menurut Kusumastuti (2009: 2) dalam jurnal Pendidikan Seni Tari Pada Anak Usia Dini Di Taman Kanak-Kanak Tadika Puri Cabang Erlangga Semarang Sebagai Proses Alih Budaya mengatakan bahwa gerak dan lagu adalah kegiatan belajar bernyanyi sambil bergerak. Gerak yang tercipta dalam pembelajaran gerak dan lagu harus memiliki makna dan simbol yang mengungkapkan tema dalam pembelajaran. Sejalan dengan hal tersebut, gerak merupakan sarana ekspresi dan mengalihkan ketakutan, kesedihan, kemarahan, kenikmatan dan sebagainya.

Berdasarkan pengertian beberapa ahli di atas maka dapat disimpulkan bahwa gerak dan lagu adalah kegiatan bernyanyi sambil bergerak sesuai dengan irama music. Gerak yang tercipta dalam pembelajaran gerak dan lagu harus memiliki makna dan simbol yang mengungkapkan tema dalam pembelajaran.

\section{Media Pembelajaran}

Menurut Gagne (dalam Miarso, 2007: 457), media pembelajaran adalah berbagai jenis komponen dalam lingkungan siswa yang dapat merangsang siswa untuk belajar. Seluruh komponen di sekitar anak dapat menjadi media pembelajaran sehingga memudahkan anak untuk menyerap informasi karena disampaikan melalui hal-hal yang dekat dengan anak. Serta dapat menjadi motivasi dan dorongan anak untuk lebih tertarik terhadap informasi yang akan disampaikan oleh guru. Sejalan dengan hal tersebut Sadiman (2008: 7) dalam buku bermain dan permainan mengatakan bahwa media pembelajaran adalah segala sesuatu yang digunakan untuk menyalurkan pesan dari pengirim ke penerima, sehingga dapat merangsang pikiran, perasaan, perhatian dan minat siswa dan dengan demikian terjadilah proses belajar.

Terdapat berbagai macam jenis media. Fadhillah (2016: 200) dalam buku bermain dan permainan menuliskan jenis media sebagai berikut:

1. Media Audio

Media audio ialah sebuah media yang digunakan dengan cara mendengarkan. Dengan kata lain, media ini hanya mengandalkan kemampuan suara, seperti radio, tape recorder dan benda-benda yang menghasilkan suara. Dalam Pendidikan anak usia dini media ini cocok pada saat menyampaikan materi dengan metode bercerita, bernyanyi atau menari.

\section{Media Visual}

Media visual ialah media yang digunakan dengan cara melihat. Biasanya media ini hanya berupa gambar-gambar, lukisan, buku, puzzle dan benda-benda lain yang dapat diamati oleh peserta didik. Dalam pendidikan anak usia dini media visual paling banyak jumlahnya dibandingkan dengan media lain.

\section{Media Audio Visual}

Media audio visual ialah sebuah media yang menggabungkan antara pendengaran dan pengelihatan. Media ini biasanya lebih menarik dibandingkan dengan media yang lain. Sebab peserta didik dapat melibatkan dua indra langsung yaitu pendengaran dan pengelihatan, diantaranya video, film dan benda-benda lain yang dapat didengar dan dilihat.

Dalam hal ini jenis media yang digunakan dalam gerak dan lagu adalah jenis media audio dimana media yang digunakan dengan cara mendengarkan yang berasal dari sumber suara. 


\section{Kriteria Pemilihan Media}

Beberapa kriteria yang perlu diperhatikan dalam memilih media menurut Azhar (2014: 74) dalam buku media pembelajaran adalah:

1. Sesuai dengan tujuan yang ingin dicapai Media dipilih berdasarkan tujuan pengajaran yang telah ditetapkan yang secara umum mengacu kepada salah satu atau gabungan dari dua atau tiga ranah kognitif, afektif, dan psikomotorik. Tujuan ini dapat digambarkan dalam bentuk tugas yang harus dikerjakan/ dipertunjukkan oleh siswa, seperti menghafal, melakukan kegiatan yang melibatkan fisik atau pemakaian prinsip-prinsip seperti sebab dan akibat, melakukan tugas yang melibatkan pemahaman konsep-konsep atau hubungan-hubungan perubahan, dan mengerjakan tugas-tugas yang melibatkan pemikiran pada tingkatan lebih tinggi. Seperti penggunaan papan plank, rock bridge untuk menstimulasi kemampuan berjalan anak, hoops dan box untuk menstimulasi kemampuan melompat anak.

2. Sesuai dengan isi pelajaran yang sifatnya fakta, konsep, prinsip, atau generalisasi.

3. Praktis, luwes, dan bertahan lama

Jika tidak tersedia waktu, dana, atau sumber daya lainnya untuk memproduksi, tidak perlu dipaksakan. Media yang mahal dan memakan waktu lama untuk memproduksinya bukanlah jaminan sebagai media yang terbaik. Kriteria ini menuntun para guru utuk memilih media yang ada, mudah diperoleh, atau mudah dibuat sendiri oleh guru. Media yang dipilih sebaiknya dapat digunakan dimana pun dan kapan pun dengan peralatan yang tersedia di sekitarnya, serta mudah dipindahkan dan dibawa kemanamana. Media agar bertahan lama dapat pula terbuat dari bahan-bahan seperti kayu, plastik dan besi ringan.

4. Guru terampil menggunakannya

Hal ini merupakan salah satu kriteria utama. Apapun media itu, guru harus mampu menggunakannya dalam proses pembelajaran.

\section{Pengelompokan sasaran.}

Media yang efektif untuk kelompok besar belum tentu sama efektifnya jika digunakan pada kelompokkecil atau perorangan. Ada media yang tepat untuk jenis kelompok besar, kelompok sedang, kelompok kecil, dan perorangan.

\section{Mutu teknis.}

Pengembangan visual baik gambar maupun fotograf harus memenuhi persyaratan teknis tertentu. Sebagai contoh, visual pada slide harus jelas dan informasi atau pesan yang ditonjolkan dan ingin disampaikan tidak boleh terganggu oleh elemen lain yang berupa latar belakang.

Upaya pemberian stimulasi membutuhkan media yang menarik dan interaktif untuk menunjang keberhasilan stimulasi. Hal tersebut sesuai dengan manfaat dalam menggunakan media yang disebutkan oleh Asnawir, dkk (dalam Fadillah, 2016: 197). Beliau menuliskan bahwa media dapat mengatasi keterbatasan pengalaman yang dimiliki oleh anak, media dapat mengatasi ruang kelas, media memungkinkan adanya interaksi langsung antara siswa dan lingkungan, media dapat menjadikan keseragaman pengamatan, media dapat menanamkan konsep dasar yang benar, konkret dan realitas, media dapat membangkitkan keinginan dan minat yang baru, media dapat membangkitkan motivasi siswa untuk belajar, serta media dapat memberikan pengalaman dari abstrak menjadi konkret.

Pemilihan media yang menarik harus memperhatikan jenis-jenis media diantaranya terdapat media audio, media visual, dan juga media audio visual. Media audio merupakan media yang mengandalkan kemampuan suara seperti radio, tape recorder, alat-alat musik serta benda-benda yang dapat menghasilkan suara. Media audio dapat dimanfaatkan sebagai media dalam menstimulasi motorik kasar anak usia dini yang digabungkan dengan metode gerak dan lagu.

Widhianawati (2011: 2) dalam penelitiannya yang berjudul Pengaruh Pembelajaran Gerak Dan Lagu Dalam Meningkatkan Kecerdasan Musikal Dan Kecerdasan Kinestetik Anak Usia Dini mengatakan bahwa pembelajaran gerak dan lagu merupakan sebuah kegiatan dalam bermain sambil belajar dan belajar sambil bermain, aktivitas yang dilakukan melalui gerak dan lagu diharapkan akan menyenangkan anak sekaligus menyentuh perkembangan bahasa, kepekaan akan irama musik, perkembangan motorik, rasa percaya diri, serta keberanian mengambil resiko. 
Hasil observasi yang dilakukan pada bulan November-Desember tahun 2017 di salah satu sekolah taman kanak-kanak mengenai stimulasi motorik kasar yang dilakukan di sekolah tersebut ditemukan bahwa pemberian stimulasi untuk kemampuan perkembangan motorik anak adalah menggunakan senam satu minggu sekali, eskul sepak bola untuk anak laki-laki yang dilakukan seminggu sekali, dan juga eskul tari untuk anak perempuan yang dilakukan seminggu sekali.

Berdasarkan uraian mengenai kemampuan motorik dan media stimulasi di atas, maka tujuan penelitian ini adalah untuk mengetahui bagaimana Stimulasi Gerak Lokomotor Usia 14 Tahun di Little Jack Gym and Preschool.

\section{METODE PENELITIAN}

Metode yang digunakan dalam penelitian ini adalah metode kualitatif. Metode kualitatif merupakan prosedur penelitian yang menghasilkan data deskriptif berupa kata-kata tertulis atau lisan dari orang-orang dan perilaku yang dapat diamati, berupa gambar, dan bukan angka-angka (Moleong, 2010: 11).

Penelitian dilakukan sejak bulan April-Agustus 2018 yang diawali dengan melakukan studi literatur, survei, observasi awal, pelaksanaan sampai penulisan laporan penelitian. Penelitian ini dimaksudkan untuk memperoleh informasi mengenai stimulasi motorik kasar melalui metode gerak dan lagu di Little Jack Gym and Preschool. Sumber data primer pada penelitian ini adalah koordinator dan guru. Teknik pengumpulan data yang digunakan ialah observasi, wawancara dan dokumentasi. Aspek yang diperoleh meliputi stimulasi motorik kasar dan media yang digunakan. Teknik analisis data menggunakan model Miles and Huberman melalui tahapan proses pengumpulan data, reduksi data, penyajian data, dan penarikan kesimpulan.

\section{HASIL DAN PEMBAHASAN}

Pemberian stimulasi menggunakan gerak dan lagu yang dilakukan Little Jack Gym and Preschool dilakukan dengan bantuan dari orang tua khususnya untuk anak kelompok usia Runner karena masih mempunyai fokus yang kurang dan belum mandiri. Berdasarkan Peraturan Menteri Nomor 146 Tahun 2014, pada usia 12-24 bulan kemampuan anak sudah dapat berjalan sendiri tanpa bantuan, dapat berlari lurus ke depan serta dapat melompat di tempat. Namun hasil penelitian yang dilakukan di Little Jack Gym And Prechool menunjukkan bahwa kelompok usia runner yang berada di usia 16-24 bulan, pada kemampuan berjalan masih memerlukan bantuan dari orang tua dikarenakan masih memiliki fokus dan keseimbangan yang kurang, serta pada kemampuan berlari dan melompat masih pada upaya pengenalan, dengan pertimbangan pada kelompok usia Runner di Little Jack Gym And Preschool merupakan anak-anak yang baru belajar berjalan.

Stimulasi kemampuan berjalan dilakukan dengan cara berjalan di atas set up dan diiringi musik, berjalan mengikuti lagu walk jump run dengan bantuan orang tua, pada kemampuan berlari baru sebatas pengenalan dengan pertimbangan pada usia ini anak masih membutuhkan bantuan orang lain dan juga mempunyai keseimbangan yang masih kurang, pada kemampuan melompat dengan pertimbangan pada usia ini anak masih membutuhkan bantuan orang lain dan juga mempunyai keseimbangan yang masih kurang Set up, thamborine Welcome To Little Jack, Walk Jump Run, Chocho Train dan Good Bye Song.

Pada anak usia 2-3 tahun (kelas eksplorer) stimulasi kemampuan berjalan dilakukan dengan cara berjalan di atas set up dengan pengawasan orangtua. Untuk kemampuan berlari distimulasi dengan cara berlari mengikuti lagu Walk Jump Run dengan didampingi orang tua dan guru. Sedangkan untuk kemampuan melompat distimulasi dengan cara mengikuti lagu jumping jack, melompat menggunakan 3 hoops Set up, thamborine, hoops dan radio Welcome To Little Jack, Walk Jump Run, Jumping Jack, Chocho Train dan Good Bye Song.

Sementara untuk menstimulasi kemampuan berjalan anak usia 3-4 tahun (kelas Kiddos) dilakukan dengan cara berjalan di atas set up. Untuk kemampuan berlari distimulasi dengan cara berlari mengikutilagu Walk Jump Run dengan didampingi orang tua dan guru, pada kemampuan melompat distimulasi dengan cara mengikuti lagu jumping jack, melompat menggunakan 3 hoops Set up, thamborine, 
hoops dan radio Welcome To Little Jack, Walk Jump Run, Jumping Jack, Chocho Train dan Good Bye Song.

Stimulasi untuk anak kelas Kiddos juga dilakukan dengan mengajak anak berjalan di atas plank yang memiliki permukaan lebih sempit dibandingkan dengan Runner. Untuk kemampuan berlari kelompok Kiddos distimulasi menggunakan lagu "walk jump run" sama seperti kemampuan berlari kelompok Explorer, kemampuan berlari anak distimulasi dengan berlari mengikuti instruksi serta irama dari lagu dengan memperhatikan kecepatan dan tidaknya lagu tersebut dengan tanpa bantuan dari orang tua. Untuk kemampuan melompat, kelompok Kiddos diberikan stimulasi gerak dan lagu melalui iringan lagu "walk jump run" dan juga "jumping jack", dimana anak melompat dengan mengikuti instruksi serta irama darilagu, kemudian juga dengan melompat ke bawah serta ke atas dengan menggunakan 4-5 hoops atau melompat dari box dengan diriingi lagu.

Stimulasi yang dilakukan di Little Jack Gym and Preschool dalam upaya menstimulasi kemampuan motorik kasar anak dalam pemberian stimulasi sudah sesuai dengan beberapa prinsip stimulasi seperti stimulasi dilakukan dengan landasan rasa cinta dan kasih sayang; selalu menunjukkan sikap dan perilaku yang baik, karena anak akan meniru tingkah laku orang - orang terdekat dengannya; memberikan stimulasi sesuai dengan kelompok umur anak; serta melakukan stimulasi dengan cara mengajak anak bermain, bernyanyi, menyenangkan, tanpa paksaan dan tidak ada hukuman. Namun dalam hal penggunaan media belum disesuaikan dengan pengelompokan sasaran pada setiap usia anak seperti yang terdapat dalam kriteria pemilihan media.

Little Jack Gym and Preschool menggunakan media atau alat bantu permainansederhana seperti plank lebar, rock bridge, hoops, serta memberikan reward kepada setiap anak apabila dia berhasil atau melakukan kegiatan sesuai dengan instruksi guru seperti pemberian stamp, stiker, dan kata-kata pujian berupa good job dan very good. Hal tersebut sesuai denganprinsip dasar pemberian stimulasi yang disampaikan Kementerian Kesehatan RI (2012: 12) dalam pedoman deteksi dini tumbuhkembang balita yakni menggunakan alat bantu/ media sederhana yang aman dan berada di sekitar anak, serta beri pujian bila perlu anak diberikan hadiah atas keberhasilannya.

Selain media tersebut, Little Jack Gym and Preschool juga menggunakan media audio dalam proses pembelajarannya yakni menggunakan radio dimana anak bergerak dengan iringan musik dan lagu dari radio serta alat musik instrumen seperti Tamborine dan Marakas yang digunakan sebagai pengiring lagu pada saat anak bergerak mengikuti lagu. Hal ini sebagaimana yang dikatakan oleh Fadhillah (2016: 200) dalam buku bermain dan permainan bahwa salah satu jenis media terdapat adalah media audio yang merupakan sebuah media yang digunakan dengan cara mendengarkan. Dengan kata lain, media ini hanya mengandalkan kemampuan suara, seperti radio, tape recorder dan benda-benda yang menghasilkan suara. Di dalam pendidikan anak usia dini media ini dapat digunakan pada saat menyampaikan materi dengan metode bercerita, bernyanyi atau menari.

\section{SIMPULAN DAN SARAN}

Kesimpulan pada penelitian ini ialah pertama, stimulasi gerak lokomotor pada anak usia 1-4 tahun yang meliputi kemampuan berjalan, berlari dan melompat dilakukan dengan menggunakan lagu walk jump run, chochoc train, welcome to little jack, serta good bye song; kedua, Little Jack Gym And Preschool sudah menerapkan stimulasi sesuai dengan prinsip-prinsip stimulasi gerak lokomotor namun belum disesuaikan dengan usia atau kelompok anak seperti yang terdapat pada kriteria pemilihan media yang harus menggunakan media sesuai harus mengelompokan sasaran. Ketiga, stimulasi gerak dan lagu sudah menggunakan media namun perlu diklasifikasikan sesuai dengan karakteristik masing-masing kelompok usia sesuai dengan kriteria pemilihan media seperti memperhatikan kelompok anak termasuk ke dalam bagian kelompok kecil, sedang atau besar.

Berdasarkan hasil penelitian, maka saran yang dapat disampaikan adalah sebagaiberikut: pertama, sebaiknya pihak sekolah memberikan kegiatan dengan memperhatikan Peraturan Menteri Nomor 146 Tahun 2013 agar motorik kasar anak dapat berkembang sesuai tahap perkembangannya. Kedua, sebaiknya pihak 
guru menggunakan media pembelajaran yang sesuai dengan tingkat usia anak agar kemampuan anak dapat berkembang sesuai dengan usianya, dan ketiga, sebaiknya orangtua melanjutkan stimulasi motorik kasar anak di rumah sehingga ini menjadi kolaborasi yang baik antara pihak sekolah dan orang tua. Keempat, sebaiknya guru juga melakukan prinsip-prinsip setimulasi secara bertahap berdasarkan usia anak, memberikan kesempatan yang sama kepada anak laki-laki dan perempuan, serta memberikan hadiah pada setiap keberhasilan anak.

\section{DAFTAR PUSTAKA}

Arsyad, A. (2014). Media pembelajaran. Jakarta: PT. Rajagrafindo Persada

Beaty, J.J. (2013). Observasi perkembangan anak usia dini. Jakarta: Fajar Interpratama Mandiri.

Decaprio, R. (2013). Aplikasi teori pembelajaran motorik di sekolah. Yogyakarta: Diva Press.

Departemen Kesehatan RI. (2012). Pedoman deteksi dini tumbuh kembang balita. Jakarta.

Direktorat Pembinaan Taman Kanak-Kanak Dan Sekolah Dasar 2008. Pengembangan kemampuan motorik kasar di taman kanakkanak. Jakarta: Departemen Pendidikan Nasional.

Maimunah, H. (2009). PAUD (Pendidikan Anak Usia Dini). Yogyakarta: DIVA Press.

Hastuti. (2012). Psikologi perkembangan anak. Jakarta: Tugu Publisher.
Rahyubi, H. (2012). Teori-teori belajar dan aplikasi pembelajaran motorik. Bandung: Nusa Media.

Herdiana, I. Psikologi perkembangan dan pendidikan anak usia dini sebuah bunga rampai. Jakarta: Fajar Interpratama Mandiri.

Kamtini, D.T., Husni, W. (2005). Bermain melalui gerak dan lagu di taman kanakkanak. Jakarta: Departemen Pendidikan Nasional.

George, S.M. (2012). Dasar-dasar pendidikan anak usia dini (PAUD). Jakarta: Indeks.

Mulyasa. (2012). Manajemen Paud. Bandung: Remaja Rosdakarya.

Diana, M. (2010). Psikologi bermain anak usia dini. Jakarta: Kencana Prenda Media Group.

Nursalam. (2005). Asuhan keperawatan bayi dan anak (untuk perawat dan bisan). Jakarta: Salemba Medika.

Papalia, O. (2009). Perkembangan manusia, penerjemah brian marswandy. Edisi 10. Jakarta: Salemba Humanika.

Peraturan Menteri Pendidikan Dan Kebudayaan Republik Indonesia Nomor 137 Tahun 2013 tentang standar nasional pendidikan anak usia dini.

Peraturan Menteri Pendidikan Dan Kebudayaan Republik Indonesia Nomor 146 Tahun 2014 tentang kurikulum 2013 pendidikan anak usia dini.

Samsudin. (2008). Pembelajaran motorik di taman kanak-kanak. Jakarta: Prenada Media

Soetjiningsih. (2010). Bahan ajar: ilmu tumbuh kembang remaja dan permasalahannya. Jakarta: Sagung Seto. 